\title{
Changes in desiccation tolerance and respiratory rates of immature Caesalpinia echinata Lam. seeds ${ }^{1}$
}

\author{
Ana Clara Ferreira Baptista Araujo ${ }^{2}$, Claudio José Barbedo ${ }^{2 *}$
}

\begin{abstract}
Seed storage is an important tool for ex situ conservation. Orthodox seeds can be stored for long periods, but recalcitrant seeds generally only for short periods. There is wide variation in the degree of desiccation tolerance between orthodox and recalcitrant seeds, leading authors to suggest levels of recalcitrance and, more recently, that there are variations in the stage of maturity at seed dispersal. Thus, recalcitrant behavior would be a result of premature dispersal from the mother plant. In this study, we sought to establish physiological relationships between different stages of development of immature orthodox Caesalpinia echinata seeds and the stages described for recalcitrant seeds to verify similarity of behavior. Therefore, we analyzed the desiccation tolerance of seeds collected at different ages, with and without PEG treatment, at different levels of drying ( $40 \%, 30 \%, 20 \%$ and 10\% water content, wet basis). Changes in water potential, germination, vigor, and respiratory rates of the seeds were analyzed, and the results showed that: 1) desiccation tolerance increased as maturation proceeded; 2) PEG treatment did not induce desiccation tolerance; and 3) PEG treatment decreased the seed oxidation rate, which is the main factor in rapid seed deterioration of C. echinata in storage.
\end{abstract}

Index terms: desiccation tolerance, osmopriming, maturation, oxidative process.

\section{Alterações na tolerância à dessecação e nas taxas respiratórias de sementes imaturas de Caesalpinia echinata Lam.}

\begin{abstract}
RESUMO - O armazenamento de sementes é uma importante ferramenta para a conservação ex situ. Sementes ortodoxas podem ser armazenadas por longos períodos, mas as recalcitrantes apresentam curta longevidade. Há grande variação na tolerância à dessecação entre ambas, sugerindo a existência de níveis de recalcitrância e, mais recentemente, a existência de variações no estádio de maturação quando são dispersas. Assim, o comportamento recalcitrante seria resultado da dispersão prematura dessas sementes pela planta-mãe. Neste trabalho procurou-se estabelecer relações fisiológicas em diferentes estádios imaturos das sementes ortodoxas de Caesalpinia echinata com as descritas para sementes recalcitrantes, visando a verificar comportamentos semelhantes. Para tanto, analisou-se a tolerância à dessecação, natural e induzida por solução osmótica de PEG, das sementes das diferentes idades até teores de água de 40\%, 30\%, 20\% e 10\% de água (base úmida). Avaliaram-se alterações no potencial hídrico, na germinação, no vigor e nas taxas respiratórias das sementes. Foi observado que: 1) houve avanço da tolerância à dessecação com a evolução na maturação; 2) não houve indução de tolerância à dessecação com PEG; 3) este reduziu as taxas de oxidação das sementes, principal fator da sua rápida deterioração em armazenamento.
\end{abstract}

Termos de indexação: tolerância à dessecação, osmocondicionamento, maturação, processos oxidativos.

\section{Introduction}

Seed banks allow conservation of wide genetic variability in a simple manner in a small space (FAO, 2013), but they require extensive knowledge of the levels of desiccation tolerance of the seeds of each species. However, there is a great need for scientific information that would allow technological development for efficient production and storage of seeds of tropical species, especially those native to Brazil, which have a wide range of behavior (Davide et al., 2003; Walters, 2015).

Currently, long-term storage is only viable for seeds tolerant to desiccation (orthodox seeds). For the others, there

\footnotetext{
${ }^{1}$ Submitted on 08/11/2016. Accepted for publication on 02/10/2017.

${ }^{2}$ Instituto de Botânica, Núcleo de Pesquisa em Sementes, 04301-902 - São Paulo, SP, Brasil.

*Corresponding author <claudio.barbedo@pq.cnpq.br>
} 
are few studies to assist plans and actions for conservation of biological diversity (Davide et al., 2003). When seeds are desiccation intolerant (recalcitrant), they must be maintained at high moisture levels, which results in high metabolic activity, high respiratory rates, and large consumption of reserves, substantially diminishing capacity for long-term storage. In addition, in the period in which seeds have intense activity that is not directed to germination or to seedling development, metabolism may be disordered and free radicals may be released, which further hinders conservation of viability during storage and, consequently, promotes rapid seed deterioration (Marcos-Filho, 2015).

Seed response varies widely from one species to another, which leads some authors to postulate levels of recalcitrance or degrees of desiccation tolerance, oscillating from highly intolerant to highly tolerant (Barbedo et al., 2013). In addition, there are degrees of response even within the same species (Daws et al., 2006) and between seeds from the same plants in different years of production (Lamarca et al., 2013), which corroborates the inconsistency of grouping seeds from different species into categories. Even orthodox seeds have periods of sensitivity to drying during formation and maturation, and in these phases act in a manner similar to recalcitrant seeds. For that reason, studying the immature phases of orthodox seeds may make an important contribution to understanding the behavior of recalcitrant seeds (Barbedo et al., 2013).

Although acquisition of desiccation tolerance occurs quickly in orthodox seeds, there is a transitional phase between intolerance and total tolerance. This transition can be prematurely induced or prolonged by modifications of the medium or chemical manipulation. Once the process is induced, immature embryos can become tolerant to desiccation in a few days (Leduc et al., 2012) and the use of polyethyleneglycol (PEG) osmotic solutions is one way of inducing this tolerance.

The respiratory rates of the seeds and other oxidation processes are important factors to study during maturation. Information in the literature is scarce, but intense metabolic activity has been observed during embryogenesis, which requires a large energy source, provided by respiratory activity (Borisjuk and Rolletschek, 2008). In relation to oxidation processes, seeds pass through inevitable processes of formation of free radicals and reactive oxygen species through imbalances in transport of electrons of the respiratory chain during drying, and this has a clear influence on seed desiccation tolerance (Kranner and Birtic, 2005). Therefore, during seed formation, antioxidant systems need to be present and efficient. According to the model of Barbedo et al. (2013), immature orthodox seeds, just as recalcitrant seeds, could also have faults in the antioxidant systems in their desiccation intolerant phase. Therefore, the study of respiratory activity and of oxidation reactions of immature orthodox seeds could make a substantial contribution to knowledge of recalcitrant seeds (Lamarca and Barbedo, 2012).

Caesalpinia echinata Lam. (Brazilwood) seeds were initially classified as orthodox, which tolerate drying until reaching low moisture values such as $8 \%$ to $5 \%$ wet basis (Martini-Neto and Barbedo, 2015). However, unlike classic orthodox seeds, they do not tolerate storage longer than 12 months, even if low water content is maintained (Hellmann et al., 2006). These seeds stored at freezing temperatures can remain viable for at least five years (Mello et al., 2013).

Such characteristics (tolerance to desiccation and to freezing and short longevity at environmental temperature) did not allow these seeds to be placed in any of the previously described categories. In addition, Lamarca and Barbedo (2012) found that the rapid loss of viability of $C$. echinata seeds is associated with high consumption of $\mathrm{O}_{2}$ without corresponding production of $\mathrm{CO}_{2}$, which suggests other oxidation processes and the lack or inefficiency of antioxidant systems. These seeds are therefore material of great scientific interest. The aim of this study was to analyze desiccation tolerance, whether natural or induced, of C. echinata seeds at four different ages, all immature, and also analyze their respiratory rates and other oxidation processes after different levels of dehydration.

\section{Materials and Methods}

Fruits of Caesalpinia echinata Lam. were harvested from trees in the Bosque Brasil 500 (Figure 1) in Paulínia, SP, Brazil $\left(22^{\circ} 45^{\prime} \mathrm{S}, 47^{\circ} 09^{\prime} \mathrm{W}\right.$, altitude of $\left.690 \mathrm{~m}\right)$ from October to November 2014. The fruit was packed in plastic mesh bags and taken to the Seed Laboratory of the Instituto

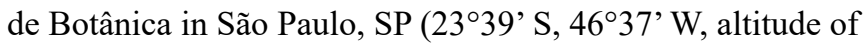
$785 \mathrm{~m}$ ), where the seeds were extracted. Seeds were extracted manually, with slight twisting of the fruit to detach the seeds, which were separated into five distinct stages of maturity, called ages, according to their size and color. Seeds of five ages were obtained, with $\mathrm{A} 0$ as the most immature and $\mathrm{A} 4$ the most mature (Figure 1). Chronological time from anthesis to each harvest (days after anthesis, DAA) was estimated through labeling of flowers at the time of anthesis and monitoring the development of fruit and seeds in regard to their external appearance.

Separation of the seeds by age was checked by evaluating the water content and the dry matter content, comparing these data with those described by Borges et al. (2005). In addition 


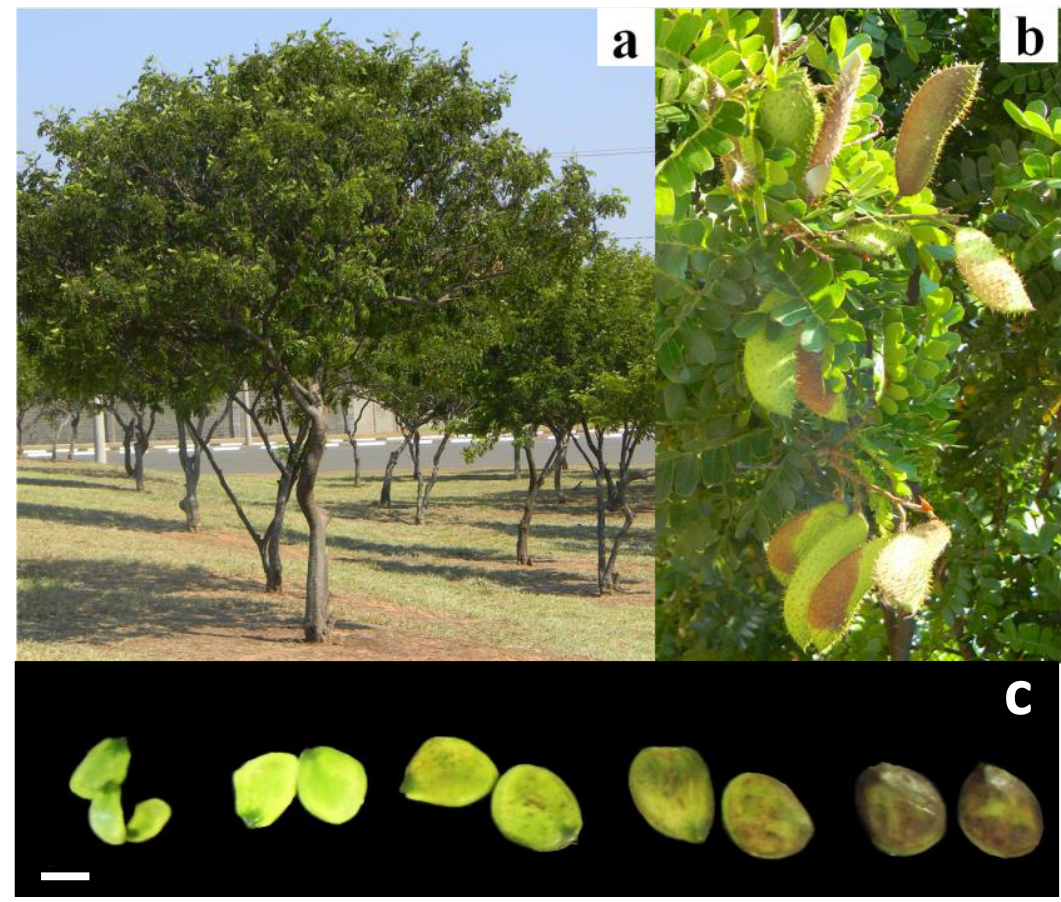

Figure 1. General appearance of trees (a) and fruits (b) of Caesalpinia echinata from which seeds (c) were obtained at the ages of A0, A1, A2, A3 and A4 (from left to right, respectively). Paulínia, SP, Brazil. Scale $=1 \mathrm{~cm}$.

to water content and dry matter content, samples of seeds of each age were taken to also characterize their water potential, their respiratory rates, and their capacity to germinate and produce normal seedlings, as described below.

The water content and the dry matter content were determined gravimetrically by the laboratory oven method at $103{ }^{\circ} \mathrm{C}$ for 17 hours, and the results were presented in percentage, wet basis, for water content, and in $\mathrm{mg}^{- \text {seed }^{-1}}$ for dry matter (Brasil, 2009).

Water potential was measured in a WP4 potentiometer (Decagon Devices, Pullman, WA, USA), which was based on determination of the dew point temperature in equilibrium with the sample examined (Delgado and Barbedo, 2012). For this test, the seeds were cut lengthwise so as to speed hygroscopic equilibrium between the sample and the air and then immediately placed in plastic capsules, which were closed. After reaching a temperature near that of the potentiometer, the capsules were opened and inserted in the evaluation chamber and results were registered in $\mathrm{MPa}$ (Lamarca et al., 2009; Martini-Neto and Barbedo, 2015).

The germination test was performed in a roll of germination paper moistened with water to saturation (Brasil, 2009). The rolls were placed in germination chambers at $100 \%$ relative humidity and constant temperature of $25{ }^{\circ} \mathrm{C}$ with continuous light (Mello and Barbedo, 2007). Evaluations were made every two days, and the number of seeds with at least $1 \mathrm{~cm}$ of primary root protrusion was registered for calculation of the percentage of seeds able to germinate as well as the number of seeds that produced normal seedlings (seedlings with a developed root system and visible first pair of leaves) for calculation of the percentage of germination (Martini-Neto and Barbedo, 2015).

The respiratory rates, that is, oxygen $\left(\mathrm{O}_{2}\right)$ consumption and carbon dioxide $\left(\mathrm{CO}_{2}\right)$ production were determined by an analyzer model ILL6600 (Illinois Instruments, Inc., Johnsburg, IL, USA), according to the methodology described by Lamarca and Barbedo (2012). The values obtained in the evaluations were divided by the total dry matter of the sample and by the incubation time, and the value of $\mathrm{O}_{2}$ or $\mathrm{CO}_{2}$ was obtained in micromols of gas per gram of dry matter per day $\left(\mu \mathrm{mol} \mathrm{gDM}^{-1}\right.$.day $\left.{ }^{-1}\right)$. The respiratory quotient (RQ) was also calculated, that is, the ratio between $\mathrm{CO}_{2}$ production and $\mathrm{O}_{2}$ consumption ( $\left.\mathrm{RQ}=\mathrm{CO}_{2} \mathrm{O}_{2}^{-1}\right)$.

The seeds of the different ages were divided into two groups. In the first, they were progressively dried until reaching water contents of $40 \%, 30 \%, 20 \%$ and $10 \%$ (designated as S40, S30, S20 and S10, respectively). After drying, they were once more evaluated in regard to water content, dry matter content, water potential, germination, and respiratory rates, as previously described. The seeds were dried in a forced-air circulation oven regulated to $40 \pm 2{ }^{\circ} \mathrm{C}$, controlling the variation between initial weight and final weight of the seeds for each predetermined water content. In the laboratory oven, the seeds were placed on 
shelves lined with Sombrite ${ }^{\circledR}$ screens in a single layer without overlapping. Drying was intermittent, alternating 8-hour drying periods with 16 hours of rest. During the resting phase, the seeds were placed in perforated plastic bags and kept in a refrigerator at approximately $7{ }^{\circ} \mathrm{C}$ until resuming drying in the laboratory oven. None of the different ages required more than one rest period. In the second group, the seeds were incubated in a polyethyleneglycol 6000 (PEG) solution at $-3 \mathrm{MPa}$ (Leduc et al., 2012) for the purpose of inducing desiccation tolerance, followed by the same drying procedures and evaluations as the previous group. For this incubation, the seeds were placed between two sheets of germination paper previously saturated with the PEG solution, kept for 24 hours at $25^{\circ} \mathrm{C}$, and then quickly rinsed in distilled water and dried on the surface with dry germination paper. They were then immediately dried in a laboratory oven until reaching the pre-established moisture levels, as previously described. Seeds of the A0 age could not be included in the drying treatments and incubation in PEG, because of their low germination capacity, as will be discussed below.

The experiments were carried out in a completely randomized design in a $4 \times 2$ factorial arrangement (4 levels of drying, with or without PEG) within each age, with four replications of fifteen seeds for the germination tests, three replications of fifteen seeds for the respiratory rates, and three replications of five seeds for water content, dry matter, and water potential. The data were subjected to analysis of variance and, when significant, means were compared by the Tukey test, always at the level of $5 \%$ (Ferreira, 2008).

\section{Results and Discussion}

Progressive advancement of maturation in seeds from A0 to A4 resulted in progressive reduction in water content and increase in dry matter content (Figure 2), parameters that are frequently considered as indicators of the point of maturation of seeds (Lazzaroto et al., 2011; Marcos-Filho, 2015; Silva et al., 2015; Pires Neto et al., 2016). Nevertheless, according to the parameters described by Borges et al. (2005) for Caesalpinia echinata (that is, seed coat color, dimensions, water content, and dry matter content), seeds of all the ages in this study can be considered as still immature (Figure 2). Along with reduction in water content, the seeds had progressively lower water potential $(\Psi)$ from A1 to A3 (Figure 2a), exhibiting a probable increase in the binding sites of water because of the larger amount of dry matter deposited.

The low values of $\Psi$ in the seeds of $\mathrm{A} 0$, which were highly hydrated (near $70 \%$ water content, Figure $2 \mathrm{~b}$ ), may be the result of impreciseness in evaluation due to the
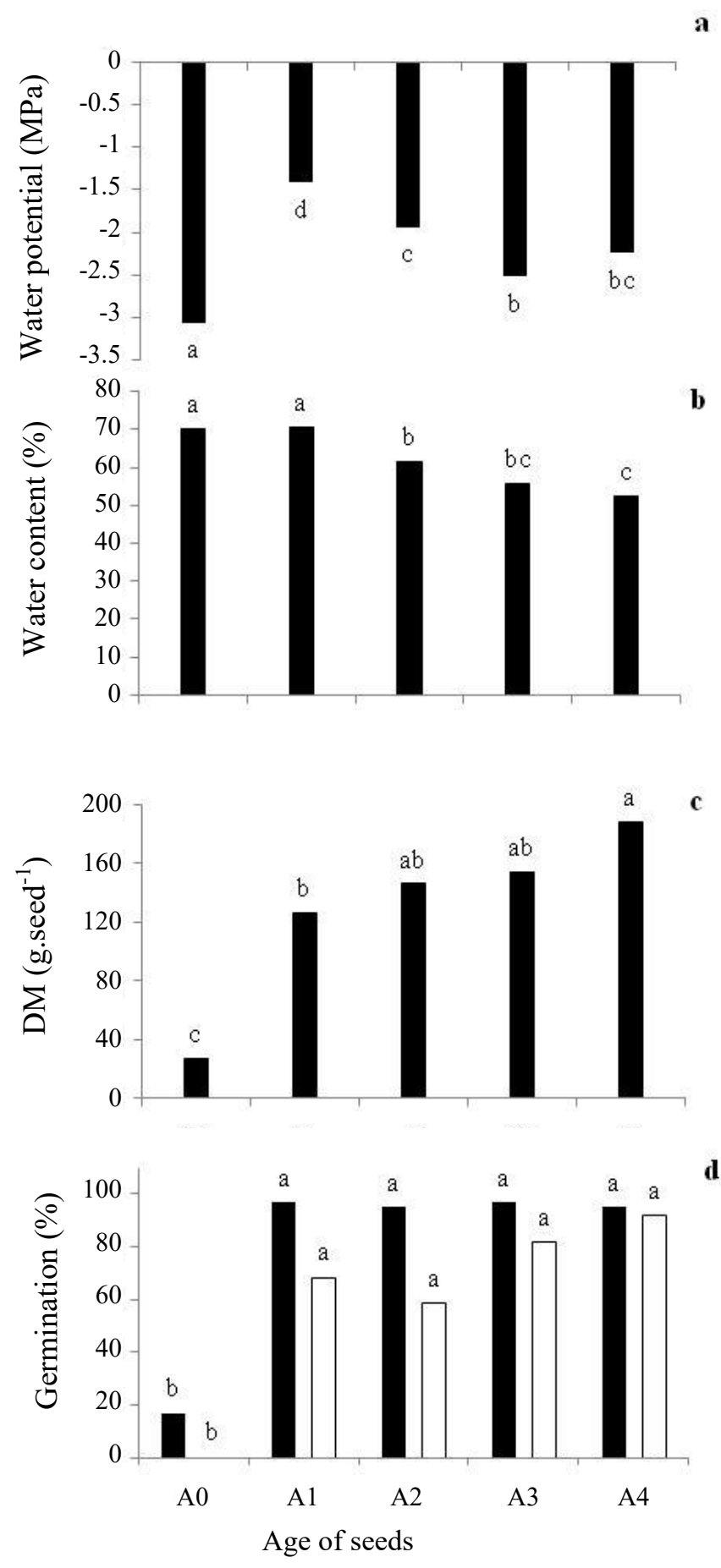

Figure 2. Water potential (a, in MPa), water content (b, in $\%$, wet basis), dry matter content - DM (c, in mg.seed ${ }^{-1}$ ), seeds able to germinate (d, black columns), and germination ( $\mathrm{d}$, white columns) of Caesalpinia echinata seeds at different ages (A0, A1, A2, A3, A4) immediately after harvest. Mean values followed by the same letter do not differ by the Tukey test at $5 \%$. 
low weight of these seeds obtained from fruit harvested at less than $30 \mathrm{DAA}$, which corresponds to half the total maturation cycle, according to Borges et al. (2005). It is important to note that the dry matter of seeds in the A0 stage was near $30 \mathrm{mg}^{-s} \mathrm{de}^{-1}$ (Figure 2c), that is, less than $1 / 6$ the dry matter of seeds of the last age studied (A4, with around $\left.190 \mathrm{mg} \cdot \mathrm{seed}^{-1}\right)$ and $1 / 10$ of that expected for mature seeds (Borges et al., 2005). Upon obtaining the results of seeds able to germinate and of germination, this first stage of development (A0) was not included in the drying treatments, because of the low germination capacity (Figure 2d). At age A1, the $\Psi$ of $-1.4 \mathrm{MPa}$ (Figure 2a) indicates type 5 water, suggesting high metabolic activity of the seeds, with the possibility of accelerated deterioration reactions (Marcos-Filho, 2015), as observed in recalcitrant seeds (Barbedo et al., 2013; Walters et al., 2013).

Drying of seeds of different ages resulted in water content values very near those desired (Table 1), except for S40 of A1, which was discarded from the experiment because it was far from reaching the expected value. These dryings brought the seed hydration level from type 4 water $(-1.5$ to $-4.0 \mathrm{MPa})$ to type 3 in S40 (-4.0 to $-11.0 \mathrm{MPa})$ and type 2 in S30, S20, and S10 (-11 to $-150 \mathrm{MPa})$. Therefore, type $1(<-150 \mathrm{MPa})$ was not reached, which would be recommended for storage of orthodox seeds (Walters, 2015). In contrast, the values considered as the lower limit for separating tolerant seeds from those sensitive to desiccation, that is, removal of all type 3 water, were exceeded in S10. After PEG treatment, followed by drying, the values of water content were near those of the untreated seeds (Table 1), except for some small differences that did not come to $4 \%$. Water potential, for its part, showed greater changes, especially in seeds dried to S10, in which PEG treatment resulted in more negative water potentials, that is, with greater water retention. This was also observed by Leduc et al. (2012), who attributed this decrease to a probable increase in water binding sites, arising from PEG treatment.

Tolerance to drying increased in C. echinata seeds as they matured, in accordance with the behavior of orthodox seeds (Walters, 2015). In other words, the greater the ages tested of the seeds, the greater the amount of water to be removed before beginning loss in the capacity of seeds to maintain their germination percentages and percentage of seeds able to germinate (Figure 3). Whereas less than half of the A1 seeds were tolerant to desiccation (Figure 3a), nearly all those of A4 were tolerant (Figure 3g). The former exhibited a steep decline in percentage of seeds able to germinate when the water content fell to around $15 \%$, and germination decreased to less than one third already in the first levels of drying (Figure 3).

PEG treatment in seeds of the A1 age decreased desiccation tolerance even more - the capacity for producing normal seedlings was 7\% in S30 and was eliminated in S20 (Figure 3b). Thus, at that age, osmotic treatment for the purpose of increasing the levels of tolerance to desiccation were not only ineffective, but also harmful, reducing survival rates and vigor.

As maturation advanced, seeds of the A2 age that were dried responded in a way similar to those of A1 in regard to seeds able to germinate, but exhibited greater tolerance to desiccation when germination percentage was analyzed (Figure 3c). Seeds at the A2 age still maintained around 60\%

Table 1. Water content and water potential of C. echinata seeds at four ages (A1 to A4) under different levels of drying (S40: 40\%, S30: 30\%, S20: 20\%, S10: 10\%), without or with pre-treatment in PEG solution.

\begin{tabular}{|c|c|c|c|c|c|c|c|c|}
\hline \multirow{2}{*}{ Drying level } & \multicolumn{4}{|c|}{ Drying without pre-treatment with PEG } & \multicolumn{4}{|c|}{ Drying after treatment with PEG } \\
\hline & A1 & A2 & A3 & A4 & A1 & A2 & A3 & A4 \\
\hline & \multicolumn{8}{|c|}{ Water content $(\%)$} \\
\hline S0 & $70.5 \mathrm{aA}$ & $61.6 \mathrm{aA}$ & $55.8 \mathrm{aA}$ & $52.3 \mathrm{aA}$ & $70.5 \mathrm{aA}$ & $61.6 \mathrm{aA}$ & $55.8 \mathrm{aA}$ & $52.3 \mathrm{aA}$ \\
\hline S40 & $*$ & $39.6 \mathrm{bA}$ & $38.5 \mathrm{bA}$ & $35.5 \mathrm{bA}$ & $*$ & $39.5 \mathrm{bA}$ & $40.1 \mathrm{bA}$ & $39.2 \mathrm{bB}$ \\
\hline $\mathrm{S} 30$ & $31.6 \mathrm{bA}$ & $32.0 \mathrm{cA}$ & $27.7 \mathrm{cA}$ & $28.8 \mathrm{cA}$ & $30.0 \mathrm{bB}$ & $34.8 \mathrm{cA}$ & $31.1 \mathrm{cB}$ & $26.0 \mathrm{cB}$ \\
\hline $\mathrm{S} 20$ & $18.7 \mathrm{cA}$ & $19.1 \mathrm{dA}$ & $21.1 \mathrm{dA}$ & $20.9 \mathrm{dA}$ & $17.8 \mathrm{cB}$ & $21.4 \mathrm{dA}$ & $20.0 \mathrm{dA}$ & $17.6 \mathrm{~dB}$ \\
\hline S10 & $14.6 \mathrm{dA}$ & $12.7 \mathrm{dA}$ & $12.5 \mathrm{eA}$ & $12.0 \mathrm{eA}$ & $11.6 \mathrm{~dB}$ & $12.2 \mathrm{eA}$ & $10.6 \mathrm{eA}$ & $10.8 \mathrm{eA}$ \\
\hline \multicolumn{9}{|c|}{ Water potential (-MPa) } \\
\hline S0 & $1.4 \mathrm{aA}$ & $1.9 \mathrm{aA}$ & $2.5 \mathrm{aA}$ & $2.2 \mathrm{aA}$ & $1.4 \mathrm{aA}$ & $0.9 \mathrm{aA}$ & $2.5 \mathrm{aA}$ & $0.2 \mathrm{aA}$ \\
\hline S40 & * & $7.4 \mathrm{bA}$ & $5.6 \mathrm{bA}$ & $7.7 \mathrm{bA}$ & $*$ & $7.7 \mathrm{bA}$ & $5.7 \mathrm{bA}$ & $5.8 \mathrm{bA}$ \\
\hline $\mathrm{S} 30$ & $14.0 \mathrm{bA}$ & $12.5 \mathrm{cA}$ & $11.5 \mathrm{cA}$ & $10.5 \mathrm{cA}$ & $15.8 \mathrm{bA}$ & $11.0 \mathrm{cA}$ & $10.4 \mathrm{cA}$ & $14.3 \mathrm{cA}$ \\
\hline $\mathrm{S} 20$ & $38.2 \mathrm{cA}$ & $39.2 \mathrm{cA}$ & $24.5 \mathrm{cdA}$ & $24.6 \mathrm{cdA}$ & $38.3 \mathrm{cA}$ & $26.7 \mathrm{cA}$ & $25.5 \mathrm{cA}$ & $32.9 \mathrm{~dB}$ \\
\hline $\mathrm{S} 10$ & $64.8 \mathrm{dA}$ & $61.7 \mathrm{cA}$ & $74.4 \mathrm{~dB}$ & $81.3 \mathrm{dA}$ & $90.7 \mathrm{dA}$ & $68.8 \mathrm{cA}$ & $87.8 \mathrm{cB}$ & $104.5 \mathrm{~dB}$ \\
\hline
\end{tabular}

*Data discarded. Mean values followed by the same letter (uppercase in the lines comparing with and without PEG treatment, within each age; lowercase in the columns, comparing drying levels) do not differ among themselves by the Tukey test at $5 \%$. 
Without PEG

a

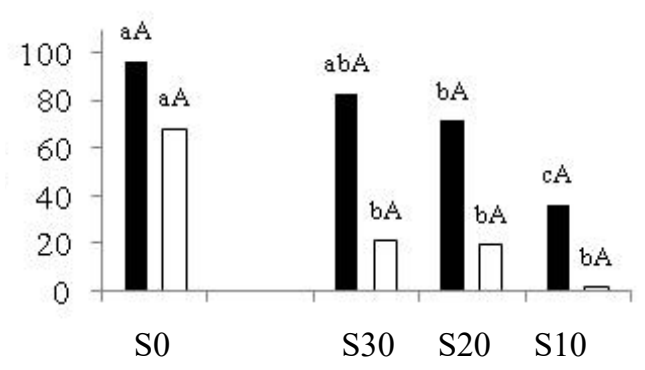

c
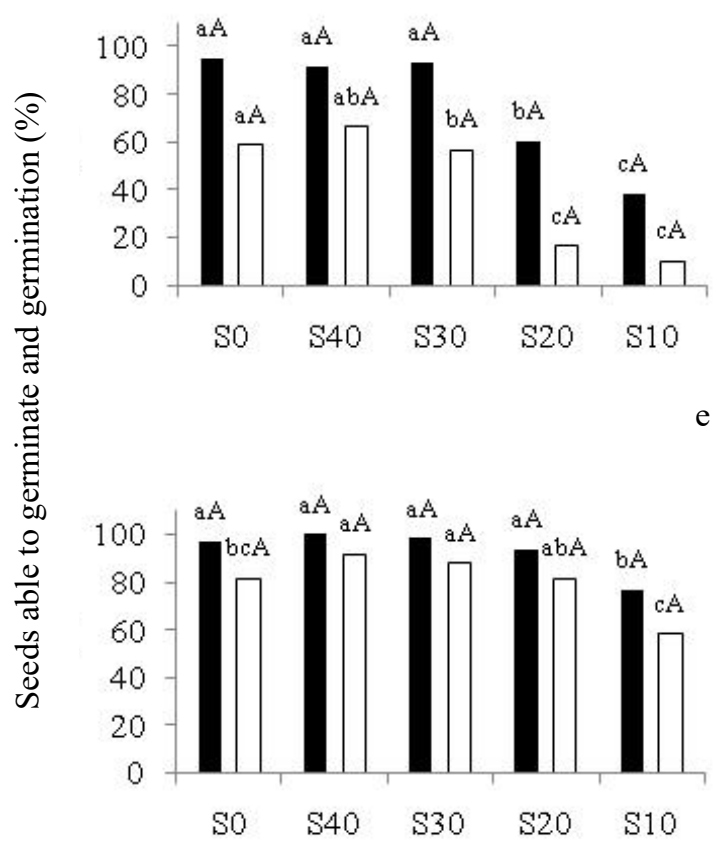

g

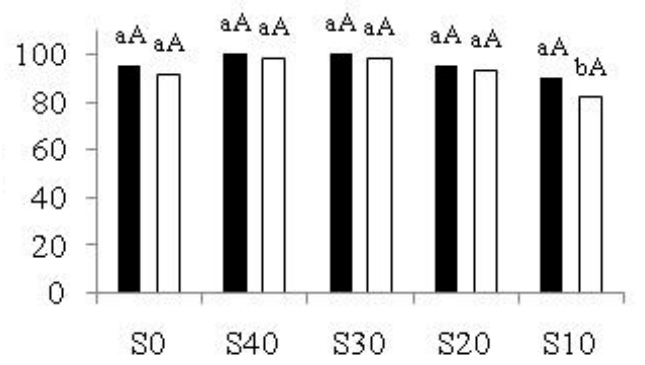

With PEG

b

A1

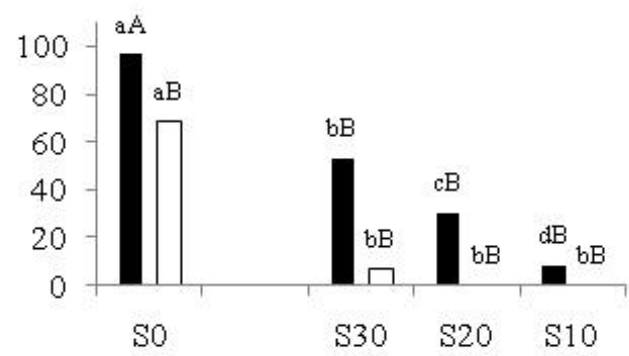

d

A2

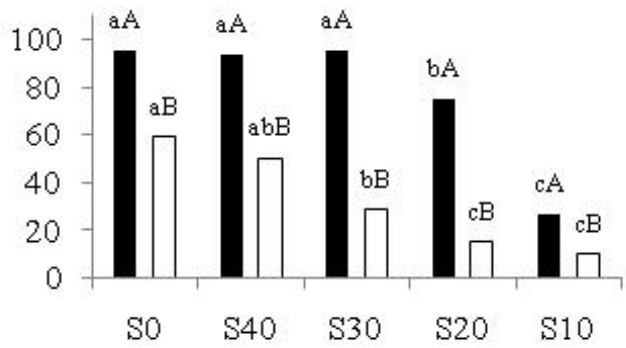

A3

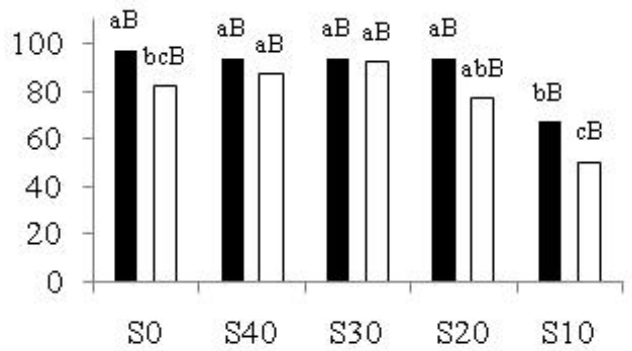

A4

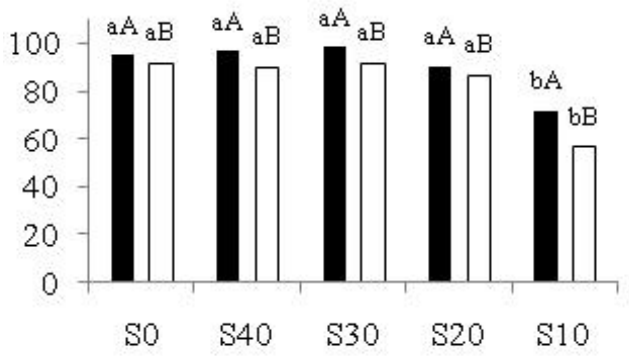

Drying levels

Figure 3. Seeds able to germinate (black columns) and germination (white columns) of C. echinata seeds at the ages A1 (a and b), A2 (c and d), A3 (e and f), and A4 (g and h) at five levels of hydration (S0, S40, S30, S20 and S10), without incubation in PEG (a, c, e and g) and with incubation (b, d, f and h). Mean values followed by the same letter (lowercase for comparison between drying levels, uppercase for comparison between seeds treated on not with PEG) do not differ by the Tukey test at 5\%. 
germination when their water content was reduced to $32 \%$, whereas seeds at the $\mathrm{A} 1$ age exhibited around $20 \%$ germination percentage at this same water content (Figure 3 and Table 1). PEG treatment in A2 seeds also led to some damage in regard to desiccation tolerance, especially observed in drying to S30, in which there was reduction to half in germination values after PEG treatment (Figure 3d). Notably, at this level of drying, in which a difference in the response of seeds treated with PEG was found, the water content (slightly greater in seeds treated with PEG than in untreated seeds) characterizes the lower limit of type 4 water, which is frequently the minimum value for storage of many recalcitrant seeds (Marcos-Filho, 2015) that, according to Barbedo et al. (2013), behave like immature orthodox seeds.

The A3 and A4 seeds already proved to be tolerant to desiccation to $\mathrm{S} 20$, with a small reduction in germination values in S10 (greater in A3 than in A4, Figures 3e, g). However, when these seeds were treated with PEG, there was loss in both the capacity for initiating germination and for producing normal seedlings (Figures $3 \mathrm{f}, \mathrm{h}$ ). Induction of tolerance to desiccation by PEG in immature C. echinata seeds seems to be possible only in a short period during their maturation, as shown by Leduc et al. (2012). In addition, according to the model proposed by Barbedo et al. (2013), artificial processes for inducing maturation applied to isolated immature seeds can slightly change their tolerance to desiccation and their longevity, but this effect would have narrow limits that are not comparable to those obtained from maturation on the mother plant. Therefore, the distortions observed in the results of treatment with PEG, sometimes beneficial, sometimes harmful, seem to fit within those reports. Therefore, the $C$. echinata seeds that could exhibit some response of induction of desiccation tolerance through the PEG treatment would be between those at the age of A2 (that did not respond to the treatment) and those at $\mathrm{A} 3$ (already tolerant).

In relation to gas exchange, measured for $C$. echinata seeds of different ages, the more mature the seeds, the lower both $\mathrm{O}_{2}$ consumption and $\mathrm{CO}_{2}$ production, indicating reduction in metabolic activity with the advance in maturation (Figures $4 \mathrm{a}, \mathrm{c})$. In addition, drying in general promoted reductions in respiratory rates; the drier the seeds, the greater the reductions.

The relation between the production of $\mathrm{CO}_{2}$ and consumption of $\mathrm{O}_{2}$ (respiratory quotient - RQ), always below 0.6 (Figure 5a), generally decreased with drying, arriving at values lower than 0.4 . Very low values of RQ suggest the presence of oxidation processes not related to respiration, as previously observed for $C$. echinata seeds stored at ambient temperature (Lamarca and Barbedo, 2012). Analyzing these results, together with those regarding germination, in which a substantial reduction in germination capacity and production of normal seedlings is observed (Figure 3), it can be inferred
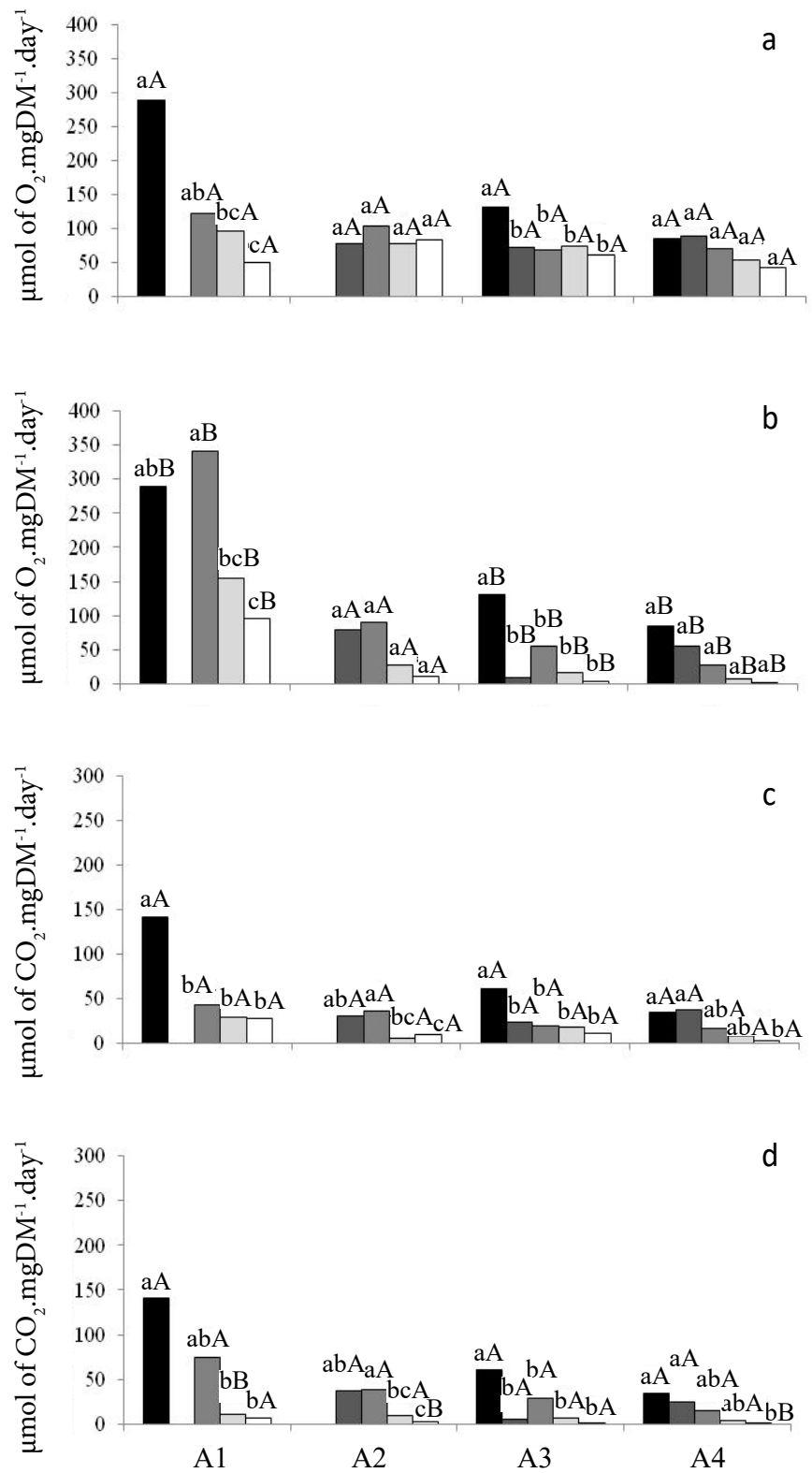

Figure 4. $\mathrm{O}_{2}$ consumption ( $\mathrm{a}$ and $\mathrm{b}$ ) and $\mathrm{CO}_{2}$ production (c and d), in $\mu \mathrm{mol} \mathrm{mgDM}^{-1}$.day ${ }^{-1}$, of $C$. echinata seeds of different ages (A1, A2, A3 and A4) at five stages of hydration (S0: black columns; S40: dark gray columns; S30: medium gray columns; S20: light grey columns; S10: empty columns) without pretreatment with PEG (a and c) or treated with PEG (b and d). Mean values followed by the same letter (lowercase for comparison between drying levels, uppercase for comparison between seeds treated or not with PEG) do not differ by the Tukey test at 5\%. 
that drying resulted in damage to seed respiratory capacity and increased oxidation processes not related to obtaining energy, especially in younger seeds.

Therefore, drying C. echinata seeds apparently promotes two simultaneous processes, which are in opposition in relation to conservation of seed viability in storage. On the one hand, it reduces respiratory activity (seen by the values of $\mathrm{CO}_{2}$ production, Figure $4 \mathrm{c}$ ), consequently reducing consumption of reserves of a metabolism that will not result in germination; but, on the other hand, it intensifies oxidation processes (seen by the RQ values, Figure 5a), among which are probably included the action of reactive oxygen species, which accelerate deterioration (Hoekstra, 2005). Lamarca and Barbedo (2012) attribute rapid deterioration of C. echinata seeds stored in non-refrigerated conditions to these oxidation processes, even when dried to water contents lower than $10 \%$.

When the seeds were treated with PEG, the respiration rates did not exhibit large changes (Figures $4 \mathrm{~b}, \mathrm{~d}$ ). However, this treatment changed the RQ ratios, especially in A4 seeds (Figure 5), which exhibited aspects different from all the other levels of development, with increasing RQ values as drying proceeded. This suggests reduction in the oxidation processes not related to respiration, which are mainly responsible for the rapid deterioration of $C$. echinata seeds.

Analysis of respiratory rates made an important contribution to understanding changes in metabolism of C. echinata seeds, both in relation to drying and their conservation in storage. For example, induction of desiccation tolerance with PEG solution did not lead to evident changes in germination percentages and in seeds able to germinate. However, when consumption and release of gases involved in respiratory and oxidation processes are analyzed, important differences were found in the metabolism of seeds when they underwent incubation in PEG solution as of A2.

The A4 seeds showed expressive reduction in $\mathrm{O}_{2}$ consumption directed to oxidation pathways other than respiration during drying when they underwent priming in PEG, suggesting that metabolism of pathways that involve oxygen was reduced. Lamarca and Barbedo (2012) showed that rapid deterioration of $C$. echinata seeds stored without refrigeration or freezing is related to oxidation processes not directed to respiration. The more the storage temperature is reduced, the lower the action of these processes and the longer the storability of these seeds may be. The present study showed that treatment
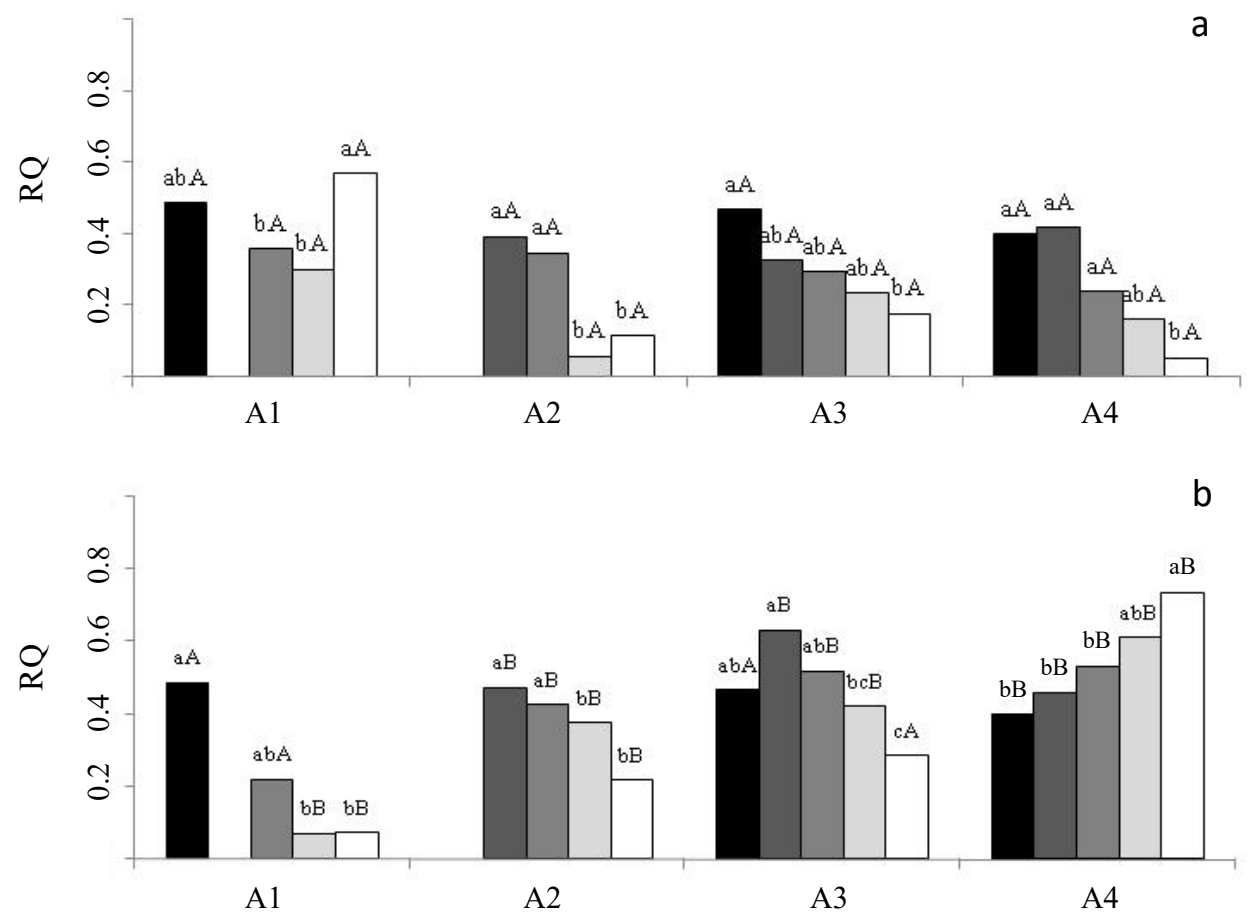

Figure 5. Respiratory quotient (RQ) in Caesalpinia echinata seeds of different ages (A1, A2, A3 and A4) in five stages of hydration (S0: black columns; S40: dary gray columns; S30: medium gray columns; S20: light gray columns; S10: empty columns), with pre-treatment with PEG (a) or treated with PEG (b). Mean values followed by the same letter (lowercase for comparison between drying levels, uppercase for comparison between seeds treated or not with PEG) do not differ by the Tukey test at $5 \%$. 
with PEG apparently can also reduce this deleterious effect of oxidation processes in C. echinata seeds. This finding can make an important contribution to conservation of the seeds of this important tropical arboreal species without the high cost of use of refrigeration or freezing.

In addition, reduction in metabolism in immature orthodox seeds with priming in PEG, especially that related to nonrespiratory oxidation processes, may have partially simulated processes involved in seed maturation itself. As seeds mature, antioxidant systems are also expanded and improved, preparing the seed for the drying phase at maturation, which will involve intense action of reactive oxygen species. This fact reinforces the model proposed by Barbedo et al. (2013) of the similarity between seeds designated as recalcitrant with immature orthodox seeds. However, also as predicted by Barbedo et al. (2013), although treatment with osmotic solutions prolongs the conditions suitable for an advance in seed development, it is not able to achieve behavior identical to that found in seeds that remained on the mother plant to more advanced stages of maturation. Future studies with the aim of prolonging these characteristics in immature orthodox seeds can deepen understanding of recalcitrant behavior under the same conditions.

\section{Conclusions}

From the results obtained in this study, we conclude that: desiccation tolerance of $C$. echinata seeds is acquired progressively during their development; PEG treatment, even if it does not induce desiccation tolerance, can reduce the oxidation rates not related to respiration, bringing a new perspective to expanding conservation of the viability of these seeds in storage.

\section{Acknowledgments}

Our thanks to the Post-graduation Program in Plant Biodiversity and Environment of the Institute of Botany (IBt) for the opportunity given to the first author for the Master's degree course; to the Seed Research Group of the IBt for use of the laboratory; to the Jardim Botânico and the city hall of Paulínia, SP, for permission to collect the fruits; to CAPES for the Master's degree scholarship granted to the first author; and to the $\mathrm{CNPq}$ for the research productivity scholarship granted to the second author.

\section{References}

BARBEDO, C.J.; CENTENO, D.C.; FIGUEIREDO-RIBEIRO, R.C.L. Do recalcitrant seeds really exist? Hoehnea, v.40, p.583-593, 2013. http://www.scielo.br/pdf/hoehnea/v40n4/01.pdf

BORGES, I.F.; GIUDICE, J.D.; BILIA, D.A.C.; FIGUEIREDORIBEIRO, R.C.L.; BARBEDO, C.J. Maturation of seeds of Caesalpinia echinata Lam. (brazilwood), an endangered leguminous tree from the Brazilian Atlantic Forest. Brazilian Archives of Biology and Technology, v.48, p.851-861, 2005. http://www.scielo.br/pdf/ babt/v48n6/27430.pdf

BORISJUK, L.; ROLLETSCHEK, H. The oxygen status of the developing seed. New Phytologist, v.182, p.17-30, 2008. http:// onlinelibrary.wiley.com/doi/10.1111/j.1469-8137.2008.02752.x/epdf

BRASIL. Ministério da Agricultura, Pecuária e Abastecimento. Regras para análise de sementes. Ministério da Agricultura, Pecuária e Abastecimento. Secretaria de Defesa Agropecuária. Brasília: MAPA/ACS, 2009, 395p. http:/www.agricultura.gov.br/arq_editor/ file/2946_regras_analise_sementes.pdf

DAVIDE, A.C.; CARVALHO, L.R.E.; CARVALHO, M.L.M.; GUIMARÃES, R.M. Classificação fisiológica de sementes de espécies florestais pertencentes à família Lauraceae quanto à capacidade de armazenamento. Cerne, v.9, p.29-35, 2003. http:// cerne.ufla.br/ojs/index.php/CERNE/article/viewFile/600/510

DAWS, M.I.; CLELAND, H.; CHMIELARZ, P.; GORIN, F.; LEPRINCE, O.; MATTHEWS, S.; MULLINS, C.E.; THANOS, C.A.; VANDVIK, V.; PRITCHARD, H.W. Variable desiccation tolerance in Acer pseudoplatanus seeds in relation to developmental conditions: a case of phenotypic recalcitrance? Functional Plant Biology, v.33, p.59-66, 2006. http://www.publish.csiro.au/paper/ FP04206.htm

DELGADO, L.F.; BARBEDO, C.J. Water potential and viability of seeds of Eugenia (Myrtaceae), a tropical tree species, based upon different levels of drying. Brazilian Archives of Biology and Technology, v.55, p.583-590, 2012. http://www.scielo.br/pdf/babt/ v55n4/a14v55n4.pdf

FAO. Food and Agriculture Organization of the United Nations. Genebank standards for plant genetic resources for food and agriculture. Roma: FAO, 2013.

FERREIRA, D.F. SISVAR: um programa para análises e ensino de estatística. Revista Symposium, v.6, p.36-41, 2008. http://www.dex. ufla.br/ danielff/meusarquivospdf/art63.pdf

HELLMANN, M.E.; MELLO, J.I.O.; FIGUEIREDO-RIBEIRO, R.C.L.; BARBEDO, C.J. Tolerância ao congelamento de sementes de pau-brasil (Caesalpinia echinata Lam.) influenciada pelo teor de água. Revista Brasileira de Botânica, v.29, p.91-99, 2006. http:// www.scielo.br/pdf/rbb/v29n1/a09v29n1.pdf

HOEKSTRA, F.A. Differential longevities in desiccated anhydrobiotic plant systems. Integrative and Comparative Biology, v.45, p.725-733, 2005. http://icb.oxfordjournals.org/ content $/ 45 / 5 / 725$.full.pdf + html 
KRANNER, I.; BIRTIC, S. A modulating role for antioxidants in desiccation tolerance. Integrative and Comparative Biology, v.45, p.734-740, 2005. http://www.ncbi.nlm.nih.gov/pubmed/21676824

LAMARCA, E.V.; BARBEDO, C.J. Short storability of Caesalpinia echinata Lam. seeds as a consequence of oxidative process. Hoehnea, v.39, p.577-586, 2012. http://www.scielo.br/pdf/hoehnea/ v39n4/06.pdf

LAMARCA, E.V.; LEDUC, S.N.M.; BARBEDO, C.J. Viabilidade e vigor de sementes de Caesalpinia echinata Lam. (pau-brasilLeguminosae) pelo teste de tetrazólio. Revista Brasileira de Botânica, v.32, p.793-803, 2009. http://www.scielo.br/pdf/rbb/ v32n4/a17v32n4.pdf

LAMARCA, E.V.; PRATAVIERA, J.S.; BORGES, I.F.; DELGADO, L.F.; TEIXEIRA, C.C.; CAMARGO, M.B.P.; FARIA, J.M.R.; BARBEDO, C.J. Maturation of Eugenia pyriformis seeds under different hydric and thermal conditions. Anais da Academia Brasileira de Ciências, v.85, p.223-233, 2013. http:/www.scielo.br/ pdf/aabc/v85n1/0001-3765-aabc-85-01-223.pdf

LAZZAROTO, M.; BELTRAME, R.; MUNIZ, F.B.; BLUME, E. Maturação fisiológica de sementes de Erythrina crista-galli L. Ciência Florestal, v.21, p.9-16, 2011. http://www.redalyc.org/ pdf/534/53418579002.pdf.

LEDUC, S.N.M.; SILVA, J.P.N.; GASPAR, M.; BARBEDO, C.J.; FIGUEIREDO-RIBEIRO, R.C.L. Non-structural carbohydrates of immature seeds of Caesalpinia echinata (Leguminosae) are involved in the induction of desiccation tolerance. Australian Journal of Botany, v.60, p.42-48, 2012. http://www.publish.csiro. $\mathrm{au} /$ ?act=view_file\&file_id=BT11236.pdf

MARCOS-FILHO, J. Fisiologia de sementes de plantas cultivadas. 2ed. Londrina: ABRATES, 2015. 660p.
MARTINI-NETO, N.; BARBEDO, C.J. Viability of brazilwood seeds (Caesalpinia echinata Lam.) stored at room temperature in controlled atmospheres. Journal of Seed Science, v.37, p.93-101, 2015. http://dx.doi.org/10.1590/2317-1545v37n2142340.

MELLO, J.I.O.; BARBEDO, C.J. Temperatura, luz e substrato para germinação de sementes de pau-brasil (Caesalpinia echinata Lam. Leguminosae - Caesalpinioideae). Revista Árvore, v.31, p.645-655, 2007. http://www.scielo.br/pdf/rarv/v31n4/09.pdf

MELLO, J.I.O; FIGUEIREDO-RIBEIRO, R.C.L.; BARBEDO, C.J. Sub-zero temperature enables storage of seeds of Caesalpinia echinata Lam. Journal of Seed Science, v.35, p.519-523, 2013. http://www.scielo.br/pdf/jss/v35n4/14.pdf

PIRES NETO, P.A.F.; PIRES, V.C.M.; MORAES, C.B.; OLIVEIRA, L.M.; PORTELLA, A.C.F.; NAKAGAWA, J. Physiological ripening of Anadenanthera colubrina (Vellozo) Brenan seeds. Journal of Seed Science, v.38, p.155-160, 2016. http://dx.doi.org/10.1590/2317$1545 \mathrm{v} 38 \mathrm{n} 2153112$

SILVA, J.P.N.; CENTENO, D.C.; FIGUEIREDO-RIBEIRO, R.C.L.; BARBEDO, C.J. Maturation of seeds of Poincianella pluviosa (Caesalpinoideae). Journal of Seed Science, v.37, p.131-138, 2015. http://www.scielo.br/pdf/jss/v37n2/2317-1537-jss-37-02-00131.pdf

WALTERS, C. Orthodoxy, recalcitrance and in-between: describing variation in seed storage characteristics using threshold responses to water loss. Planta, v.242, p.397-406, 2015. http://link.springer.com/ article/10.1007\%2Fs00425-015-2312-6

WALTERS, C.; BERJAK, P.; PAMMENTER, N.; KENNEDY, K.; RAVEN, P. Preservation of recalcitrant seeds. Science, v.339, p.915916, 2013. http://science.sciencemag.org/content/339/6122/915 